\title{
FRIEDEWALD'S LDL-CHOLESTEROL ESTIMATION FORMULA IN A JAPANESE AMERICAN POPULATION*
}

\author{
Wilfred Y. Fujimoto, M.D.
}

\begin{abstract}
Friedewald's formula is often used to estimate low density lipoprotein cholesterol (LDL-c) when direct measurement is not available. In this equation, the ratio of triglyceride (TG): cholesterol (C) in very low density lipoprotein (VLDL) is assumed to be $5: 1$. Recently it has been reported that in native Japanese the formula provided a better fit if this ratio is taken to be $4: 1$. The application of the formula was therefore examined in a sample of 229 second-generation Japanese American (Nisei) men. In this population, the $5: 1$ ratio of TG : $\mathrm{C}$ in VLDL was found to be appropriate. Thus the findings reported for native Japanese do not appear to be generally applicable to all Japanese populations.
\end{abstract}

$\mathbf{F}^{\mathrm{R}}$ RIEDEWALD'S low density lipoprotein cholesterol (LDL-c) estimation formula is often used to determine LDL-c from measurements of total cholesterol (TC), triglyceride (TG), and high density lipoprotein cholesterol (HDL-c) ${ }^{1}$ :

LDL-c $=\mathrm{TC}-(\mathrm{HDL}-\mathrm{c}+\mathrm{TG} / \mathrm{k})$.

This formula assumes that TC is found only in LDL, very low density lipoprotein (VLDL), and HDL, and that TG is carried only by VLDL. Based upon the assumption that the ratio of TG : $\mathrm{C}$ is $5: 1$ in VLDL, $\mathrm{k}$ is usually taken to be 5 .

Recently, Hata and Nakajima ${ }^{2}$ have reported that the TG : $\mathrm{C}$ ratio in VLDL is not $5: 1$ among Japanese, and that the formula provided a better fit with $k=4$ rather than $k=5$. Furthermore, they reported that a better estimation was gained if $\mathrm{k}=3$ for those with $\mathrm{TG}<150 \mathrm{mg} / \mathrm{dl}, \mathrm{k}=4$ for those with TG $150-299 \mathrm{mg} / \mathrm{dl}$, and $\mathrm{k}=5$ for

Key words:

LDL-cholesterol estimation

Friedewald equation

Japanese American those with TG $300-400 \mathrm{mg} / \mathrm{dl}$.

In view of this report, we have examined Friedewald's formula in a group of second-gener. ation Japanese American (Nisei) men to determine whether the observations of Hata and Nakajima are also relevant to this population.

\section{SUBJECTS AND METHODS}

A total of 229 Nisei men ranging in age from 45-74 yrs who were participants in a study of diabetes mellitus and cardiovascular disease were examined. The recruitment and characteristics of these subjects have been described in detail previously? Mean age ( \pm SEM) was $61.5 \pm 0.4$ yrs. Seventy-nine men had normal glucose tolerance, 72 impaired glucose tolerance (IGT), and 78 type 2 diabetes. Subjects were also grouped by their TG levels as follows: $132 \mathrm{had}$ TG $<150 \mathrm{mg} / \mathrm{dl}, 78$ had TG $150-299 \mathrm{mg} / \mathrm{dl}$, and $19 \mathrm{had} \mathrm{TG} \geqslant 300 \mathrm{mg} / \mathrm{dl}$.

Venous blood samples were collected into tubes containing EDTA $(1.5 \mathrm{mg} / \mathrm{ml})$ following a $10-12 \mathrm{hr}$ overnight fast, and blood was kept at

(Received February 29, 1988; accepted May 7, 1988)

Department of Medicine, Division of Metabolism, Endocrinology, and Nutrition (RG-26), University of Washington School of Medicine, U.S.A.

*This study was supported by NIH Grant DK 31170.

Mailing address: Wilfred Y. Fujimoto, M.D., Department of Medicine, Division of Metabolism, Endocrinology, and Nutrition (RG-26), University of Washington School of Medicine, Seattle, WA 98195, U.S.A. 
TABLE I MEAN VALUES FOR FRIEDEWALD CONSTANT $(k)$

\begin{tabular}{lrcc}
\hline & $n$ & $k$ & $S D$ \\
\hline Total Sample & 229 & 5.35 & 1.57 \\
Normal glucose tolerance & 79 & 5.47 & 1.97 \\
IGT & 72 & 5.27 & 1.31 \\
Diabetes & 78 & 5.31 & 1.34 \\
\hline
\end{tabular}

$4^{\circ} \mathrm{C}$ until plasma was separated within $60 \mathrm{~min}$ of collection. Fractions containing VLDL and LDL plus HDL were isolated by ultracentrifugation at $105,000 \mathrm{~g}, 10^{\circ} \mathrm{C}$, for $18 \mathrm{hrs}{ }^{4} \mathrm{HDL}$ was separated by precipitation of the other lipoproteins with dextran- $\mathrm{Mg}^{++5}$. $\mathrm{C}$ and $\mathrm{TG}$ were quantified in plasma and lipoprotein fractions by enzymatic methods on the Abbott ABA 200 bichromatic analyzer 5 LDL-c was calculated by difference. Thus following ultracentrifugation, subtracting HDL-c from $C$ in the LDL plus HDL fractions yielded LDL-c.

From the Friedewald equation, $\mathrm{k}$ was determined as follows:

$$
\mathrm{k}=\mathrm{TG} \div(\mathrm{TC}-\mathrm{HDL}-\mathrm{c}-\mathrm{LDL}-\mathrm{c})
$$

\section{RESULTS}

Results of the calculation of $\mathrm{k}$ for the entire group of men, for men with normal glucose tolerance, IGT, or diabetes, and for men with TG $<150 \mathrm{mg} / \mathrm{dl}$, TG $150-299 \mathrm{mg} / \mathrm{dl}$, and TG $\geqslant$ $300 \mathrm{mg} / \mathrm{dl}$ are shown in Tables I and II. In all cases, $\mathrm{k}$ was very close to 5 . Notably, $\mathrm{k}$ did not increase but rather, appeared to decrease slightly with increasing TG.

\section{DISCUSSION}

Using the Friedewald equation and measurements of TC, TG, HDL-c, and LDL-c, we have calculated $\mathrm{k}$ for a group of Japanese American men and found $\mathrm{k}$ to approximate 5 . This result suggests that Friedewald's original $\mathrm{k}=5$ is indeed appropriate for estimating LDL-c in plasma of Japanese American subjects. Furthermore, k was not found to increase with increasing TG.

These observations are quite different from the results of Hata and Nakajima ${ }^{2}$ that prompted the present analysis. Friedewald's formula assumes that the ratio of TG: $\mathrm{C}$ is $5: 1$ in VLDL. This ratio was derived from subjects in the United States. Hata and Nakajima have reported
TABLE II MEAN VALUES FOR FRIEDEWALD CONSTANT (k) BY TG LEVEL

\begin{tabular}{lrrr}
\hline \hline & $n$ & $k$ & $S D$ \\
\hline$T G<150 \mathrm{mg} / \mathrm{dl}$ & 132 & 5.66 & 1.87 \\
$T G 150-299 \mathrm{mg} / \mathrm{dl}$ & 78 & 4.99 & 0.91 \\
$T G \geqslant 300 \mathrm{mg} / \mathrm{dl}$ & 19 & 4.67 & 0.82 \\
\hline
\end{tabular}

this ratio to be $4: 1$ in Japanese subjects and have suggested that the discrepancy may be due to the different composition of the Japanese diet. If this is indeed the basis for their findings, then our observations would tend to support this since the nutritional background of Japanese Americans is generally more similar to the usual western diet than it is to the native Japanese diet.6,7

In conclusion, Friedewald's formula with $k=5$ appears to be appropriate for application in the Japanese American population. Although the observations of Hata and Nakajima may be relevant to the native Japanese population, they do not appear to be generally applicable to all Japanese populations.

\section{Acknowledgments}

I am grateful to the King County Japanese American community for the support and cooperation they have given this project, and the men who volunteered for the study. This research was also supported by facilities and services of the University Hospital General Clinical Research Center (RR 37) and the Diabetes Endo. crinology Research Center, University of Washington (DK 17047$)$. Lipid and lipoprotein determinations were performed in the Northwest Lipid Research Center Lipoprotein Laboratory, University of Washington. The skilled assistance of the nursing staff of the Clinical Research Center and the technical staff of the Northwest Lipid Research Center Lipoprotein Laboratory, the. technical assistance of Jennifer McKinlay, and the assistance of Jane Shofer with data analysis and of Janetta Shepard for typing this manuscript are gratefully acknowledged.

\section{REFERENCES}

1. FRIEDEWALD WT, LEVY RI, FREDRICKSON DS: Estimation of the concentration of lowdensity lipoportein cholesterol in plasma, without use of the preparative ultracentrifuge. Clin Chem 18: 499, 1972

2. HATA $\mathrm{Y}$, NAKAJIMA $\mathrm{K}$ : Application of Friedewald's LDL-cholesterol estimation formula to serum lipids in the Japanese population. Jpn Circ J 50: 1191, 1986

3. FUJIMOTO WY, LEONETTI DL, KINYOUN JL, NEWELL-MORRIS L, SHUMAN WP, STOLOV 
WC, WAHL PW: Prevalence of diabetes mellitus and impaired glucose tolerance among secondgeneration Japanese-American men. Diabetes 36: 721,1987

4. Manual of Laboratory Operations, Lipid Research Clinic Program. Vol 1. Lipid and lipoprotein analysis. DHEW Publication No. (NIH) 75-628. US Government Printing Office, Washington, DC, 1974, p 51

5. WARNICK GR, BENDERSON J, ALBERS J, BAILLIE EE, SEXTON B, SCHAEFER EJ, CARLSON D, HILL M, BREWER HB JR, WIEBE DA, HAZLEHURST J, COOPER GR: Dextran sulfate- $\mathrm{Mg}^{2+}$ precipitation procedure for quantitation of high-density-lipoprotein cholesterol. In Selected Methods of Clinical Chemistry, vol 10, ed by COOPER, GR, Am Assoc for Clin Chem,
Washington, DC, 1983, p 91

6. FUJIMOTO WY, HERSHON KS, KINYOUN JL, OKAMOTO J, WEINBERG $\mathrm{C}$, STOLOV WC, THOMPSON SC, GALE JL: Maturity-onset diabetes in second generation Japanese-American (Nisei) and caucasian males in Seattle, Washington. A pilot study. In Genetic Environmental Interaction in Diabetes Mellitus, Int. Congr.Series No. 549, ed by MELISH JS, HANNA J, BABA S, Excerpta Medica, Amsterdam-Oxford-Princeton, 1982, p 101

7. FUJIMOTO WY, HERSHON $\mathrm{K}$, KINYOUN J, STOLOV W, WEINBERG $\mathrm{C}$, ISHIWATA $\mathrm{K}$, KAJINUMA $\mathrm{H}$, KANAZAWA $\mathrm{Y}$, KUZUYA N: Type II diabetes mellitus in Seattle and Tokyo. Tohoku J Exp Med 141 (Suppl): 133, 1983 